\title{
Geoconservação no Geossítio Trilha Ubajara-Araticum, Parque Nacional de Ubajara, Ceará, Brasil
}

\author{
Geoconservation at Trilha Ubajara-Araticum geosite, Ubajara National Park, \\ Ceará State, Brazil
}

\author{
Suedio Alves Meira ${ }^{1 *} \varangle$ (iD), Tarsila Barbosa Dantas ${ }^{2} \varangle$ (iD), \\ Marcos Antonio Leite do Nascimento ${ }^{2} \varangle$ (iD), Edson Vicente da Silva ${ }^{1} \bowtie$ (iD \\ 1Departamento de Geografia, Universidade Federal do Ceará - Fortaleza, Ceará. \\ 2Departamento de Geologia, Universidade Federal do Rio Grande do Norte - Natal, Rio grande \\ do Norte. \\ E-mails: tarsilabdantas@hotmail.com (TBD); caxexa@yahoo.com.br (MALN); \\ cacauceara@gmail.com (EVS). \\ *E-mail para correspondência: suediomeira@gmail.com (SAM).
}

Recebido (Received): 25/03/2019 Aceito (Accepted):14/11/2019

\begin{abstract}
Resumo: O Parque Nacional de Ubajara, localizado no noroeste do Estado do Ceará, é um mosaico natural composto por floresta pluvionebular, a principal província espeleológica do estado e o contato do Glint da Ibiapaba e a depressão sertaneja, originando feições escarpadas de grande beleza cênica. A unidade de conservação também se destaca como polo de estudos científicos socioambientais, embora sejam poucos os orientados aos elementos da geodiversidade e do patrimônio geológico, resultando no desconhecimento das potencialidades dos elementos abióticos presentes. Nesse sentido, este trabalho propôs uma estratégia de geoconservação para o geossítio Trilha Ubajara-Araticum, que se caracteriza enquanto um retrato exemplar da estratigrafia da região. Para tanto realizou-se o inventário, a avaliação quantitativa e a proposição de ferramentas de valorização e divulgação. O geossítio Trilha Ubajara-Araticum é considerado de relevância nacional em todos os critérios de uso, destacando-se como espaço passível de utilização em atividades científicas, educativas e turísticas, tanto por suas aptidões como pelo baixo risco de degradação. As medidas de valorização e divulgação, compreendidas pela confecção de painel interpretativo, cartão postal, roteiro geoturístico e livro gráfico, expressam a diversidade de abordagens ambientais que o geossítio propicia, como a litológica, a geomorfológica e a paleoambiental. As propostas também expõem o caráter aplicado dos estudos em geoconservação ao integrar conceitos relativos às temáticas da interpretação ambiental, educação ambiental e geocomunicação.
\end{abstract}

Palavras-Chaves: Geodiversidade; Patrimônio geológico; Inventário.

\begin{abstract}
The Ubajara National Park (PNU) is located in the northwest sector of Ceará state (Brazil), being a natural mosaic composed by rain forest, the main espeological province in the state and the Ibiapaba Glint with the Sertaneja Basin that origins steep landforms of great scenic beauty. The conservation unit also rises as a socioenvironmental research pole though with very few works dealing with geodiversity and geoheritage elements, resulting in a lack of knowledge concerning the nature's abiotic elements. The present work proposes a geoconservation strategy for the Trilha Ubajara-Araticum geosite, where the stratigraphy of the region is best revealed. The methodology started with the inventory, followed by the quantitative assessment and the valorization proposals. The geosite is considered with national relevance according to all of the criteria used in the assessment, rising as a local for scientific, touristic and educational activities due to its characteristics and low degradation risk. Valorization proposals include interpretative panels, postcards, a touristic route and a graphic book, expressing the diverse environmental approaches possible at the site. These proposals show that geoconservation studies have a purpose, integrating environmental interpretation, environmental education and geocomunication concepts.
\end{abstract}

Keywords: Geodiversity; Geoheritage; Inventory. 


\section{Introdução}

O Parque Nacional de Ubajara (PNU) foi criado em 30 de abril de 1959 com a finalidade de garantir a integridade e os processos evolutivos do excepcional conjunto de formações geológicas e biológicas presentes. Atualmente o PNU conta com uma área de 6.288 hectares, dispostos nos municípios cearenses de Frecheirinha, Tianguá e Ubajara. A geodiversidade local é caracterizada pelo principal conjunto de feições cársticas do Estado do Ceará e pelo contato do Glint da Ibiapaba com a Depressão Sertaneja, originando feições escarpadas de grande beleza cênica.

O PNU configura um importante polo de pesquisa científica. Entre os anos de 1988 e 2013, foram concedidas 118 licenças para realização de pesquisas científicas, segundo dados fornecidos pela gestão do parque. Apesar do elevado número de investigações, poucas apresentam como foco de estudo elementos da geodiversidade, totalizando apenas oito licenças concedidas. Quando tomadas as temáticas específicas da geodiversidade, patrimônio geológico e geoconservação, não há nenhuma pesquisa realizada no período.

A ausência de estudos resulta no desconhecimento das potencialidades do ambiente abiótico do PNU para o uso em atividades de educação ambiental, no desenvolvimento turístico e no enriquecimento do conhecimento sobre as características geológicas e geomorfológicas da borda leste da Bacia do Parnaíba.

O presente trabalho teve como objetivo caracterizar, avaliar e propor medidas de valorização e divulgação para o geossítio Trilha Ubajara-Araticum, localizado em uma das áreas mais visitadas do Parque Nacional de Ubajara (Figura 1), nas proximidades do centro de visitantes e da Gruta de Ubajara. Pretende-se estabelecer um modelo para outras unidades de conservação brasileiras que apresentam potencialidades ligadas ao patrimônio geológico, mas desvalorizadas em detrimento da biodiversidade, ato que fortalece uma visão segmentada da natureza e de sua conservação, em vez de uma abordagem sistêmica e integradora.

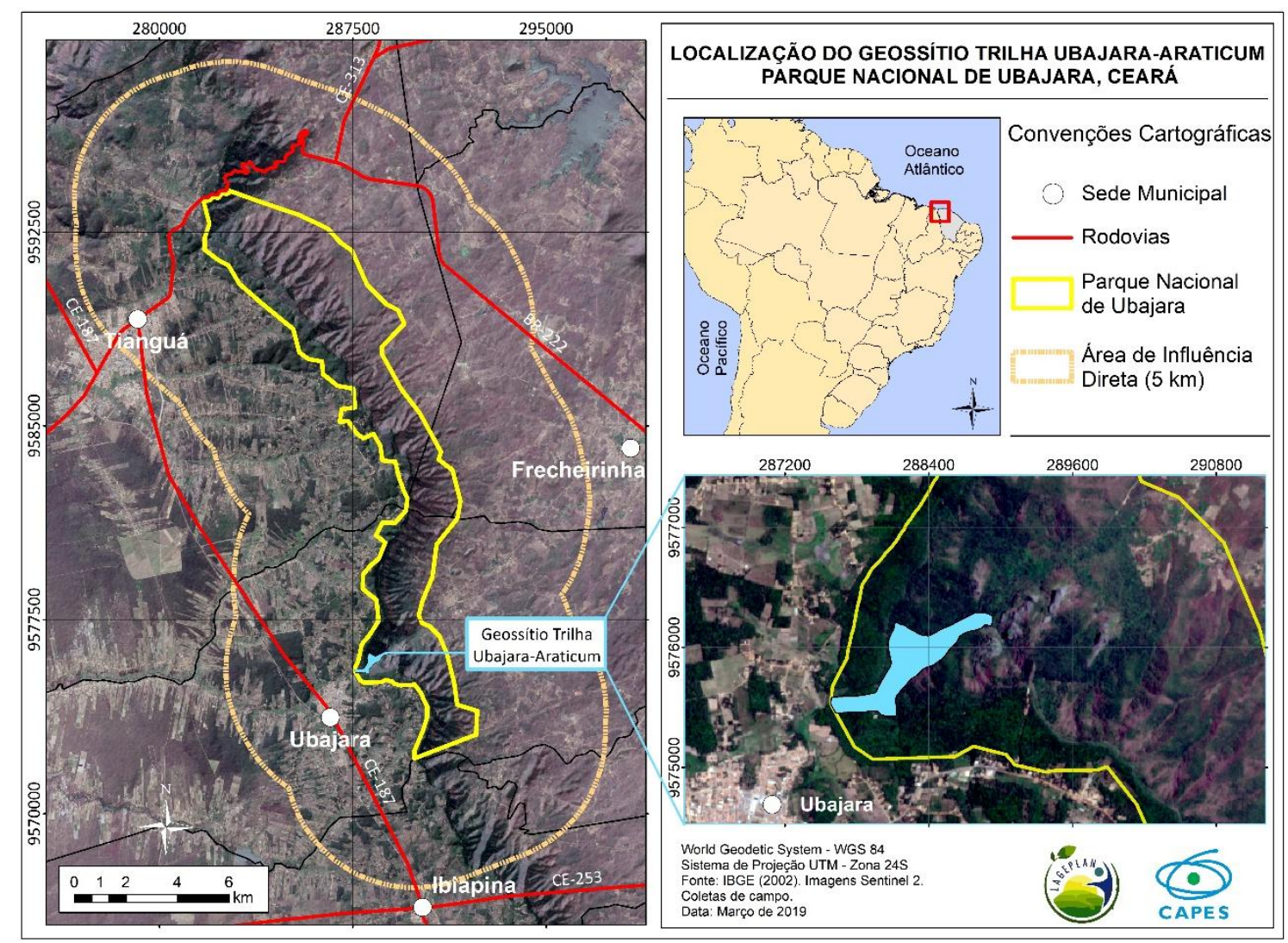

Figura 1: Localização do geossítio Trilha Ubajara-Araticum no contexto do Parque Nacional de Ubajara, Estado do Ceará. Fonte: Autoria Própria.

A escolha do geossítio Trilha Ubajara-Araticum se deve ao fato do local se caracterizar como um retrato estratigráfico da região, perpassando por afloramentos pertencentes a diferentes formações geológicas. Assim, também se pretende discutir a estratigrafia local, pontuando particularidades litológicas e incongruências com o mapeamento geológico disponível. 


\section{Materiais e Métodos}

A metodologia utilizada parte da realização de uma estratégia de geoconservação, definida por Brilha (2005) pelas etapas do inventário, avaliação, tombamento, valorização, divulgação e monitoramento de geossítios. Mediante os objetivos propostos para o trabalho, foram suprimidas as etapas de tombamento e monitoramento. Salienta-se que o estudo está inserido num esforço maior quanto a pesquisa e ao planejamento do patrimônio geológico do PNU desenvolvido no âmbito do projeto de pesquisa "Cavernas, abrigos e seu ecossistema - Pesquisas Espeleológicas e Arqueológicas - Ações de Prospecção, Valorização e Divulgação nos Parques Nacionais de Ubajara e Sete Cidades”.

Para a efetivação da pesquisa, foi realizado inicialmente trabalho de gabinete, composto pelo levantamento bibliográfico sobre os aspectos ambientais do PNU, dando ênfase às abordagens sobre a geodiversidade. Foram reunidos artigos científicos, monografias, dissertações e teses acerca da borda leste da Bacia do Parnaíba, em especial sobre as proximidades da área de estudo. Foram gerados materiais cartográficos básicos, tendo como base dados de geologia, hidrografia, solos, imagens de satélite Landsat TM 8 e de radar SRTM (Shuttle Radar Topography Mission), com $30 \mathrm{~m}$ de resolução espacial. Essa etapa teve como foco gerar conhecimento prévio sobre as características geológicas e geomorfológicas locais, sendo então um auxílio à etapa de inventário.

O inventário dos geossítios foi realizado com foco nos critérios educativo e turístico. Para o inventário utilizou-se as metodologias de seleção de locais com caraterísticas superlativas e a de classificação por categorias temáticas pré-estabelecidas (framework), instituindo um inventário sistemático (MEIRA et al., 2017). Foram definidos três frameworks para o PNU segundo critérios cronoestratigráfico e geomorfológicos, sendo eles: i) Zona com coberturas cenozoicas; ii) Coberturas paleozoicas; iii) Embasamento neoproterozoico.

Pelo uso do conjunto desses métodos foi possível inventariar os geossítios tendo como base os locais elencados na literatura e por profissionais que atuam na área, juntamente com observações oriundas dos trabalhos de campo. Sendo assim, realizou-se o que Sharples (2002) reconhece por "inventário de reconhecimento", no qual a identificação das feições significativas é dada a partir de uma revisão bibliográfica, consulta aos especialistas e trabalhos de campo.

Nos trabalhos de campo do inventário foram realizadas as análises da paisagem e a coleta de amostras de rocha em afloramentos no decorrer da trilha. Foram confeccionadas lâminas delgadas para a realização de análises microscópicas das amostras. As análises foram realizadas junto ao Laboratório de Microscopia da Universidade Federal do Rio Grande do Norte, com auxílio de microscópio petrográfico Olympus BX-41. As amostras siliciclásticas foram classificadas de acordo com seus constituintes do arcabouço (FOLK, 1968) e as amostras carbonáticas foram classificadas de acordo com critérios texturais (DUNHAM, 1962).

$\mathrm{Na}$ avaliação quantitativa dos geossítios foi adotada a metodologia do Sistema de Cadastro e Quantificação de Geossítios e Sítios da Geodiversidade (GEOSSIT), do Serviço Geológico Brasileiro (CPRM, 2018). A validade do método, que se ergue enquanto uma tentativa de padronização nacional é a abordagem de valores de uso científico, turístico e educativo dos geossítios em relação ao risco de degradação e à prioridade de proteção. Dessa forma, o método traz um contributo prático, sendo uma ferramenta para ampliar as justificativas quanto à conservação do patrimônio geológico.

$\mathrm{Na}$ valorização e divulgação foram gerados produtos gráficos com base nas informações adquiridas. Para cada proposta foi construído um plano interpretativo abordando o tema principal (o que interpretar?), elencando objetivos (o que pretende que se conheça? O que pretende que se sinta?), definindo o público alvo e os usos sugeridos (turístico, educativo e/ou científico). Todas as imagens utilizadas foram tratadas quanto a contraste, exposição, sombras, saturação e balanço de brancos e pretos no programa Adobe Lightroom. Já os desenhos do painel interpretativo e do cartão postal foram confeccionados por meio do programa Adobe Illustrator CC 2015.

\section{Aportes Conceituais em Geoconservação: Breve Discussão}

As temáticas da geodiversidade, do patrimônio geológico e da geoconservação se estabelecem enquanto campos de estudo das geociências a partir de inícios da década de 1990. Os seus pressupostos estão aliados a uma vertente conservacionista dos estudos ambientais. Para além de entender os componentes abióticos da paisagem, os estudos visam propor medidas que resultem em uma mudança de paradigma quanto à importância desses elementos para a manutenção da natureza, indo ao encontro de uma perspectiva sistêmica e integradores de conservação. 
O estabelecimento do conceito de geodiversidade foi a matriz de crescimento das temáticas supracitadas. O primeiro autor a definir geodiversidade foi Sharples (1993), tratando-a enquanto um contraponto à definição de biodiversidade, compreendendo assim o conjunto de elementos da natureza de caráter abiótico. A Royal Society for Nature Conservation traz uma abordagem que, para além do critério geológico, enfatiza a importância da geodiversidade para a manutenção da vida, ao entendê-la enquanto a "variedade de ambientes geológicos, fenômenos e processos ativos que dão origem a paisagens, rochas, minerais, fósseis, solos e outros depósitos superficiais que são suporte para a vida" (BRILHA, 2005, p. 17).

Assim como os elementos da biodiversidade, a geodiversidade compreende uma gama de valores que justifica o seu estudo e conservação. Gray (2004) delimita seis categorias de valores, que partem dos potenciais intrínseco, cultural, econômico, estético, funcional e científico/didático. $\mathrm{O}$ estudo da geodiversidade, apesar de recente enquanto um campo de análise científica, configura um novo e importante paradigma no contexto das geociências (GRAY, 2008), tendo em conta a crescente percepção de sua importância e a formulação de um corpo teórico-metodológico próprio.

Sendo a geodiversidade entendida como a totalidade de elementos abióticos, os estudos apresentavam limitações práticas na proposição de medidas de conservação, uma vez que esses elementos são necessários para o bem-estar da sociedade. Diante disso, torna-se necessário elencar locais chaves onde os elementos abióticos apresentam características excepcionais, sendo o conjunto dessas feições entendido como patrimônio geológico. Salienta-se que os presentes autores utilizam a terminologia enquanto um conceito guarda-chuva, que abarca a diversidade de patrimônio abiótico existente. Assim, o patrimônio geológico contempla especificidades, como o geomorfológico, paleontológico, mineralógico, entre outros.

Associação Europeia para a Conservação do Patrimônio Geológico (ProGEO) define geopatrimônio (terminologia também usada para definir patrimônio geológico) como uma parte integrante do patrimônio natural global, abrangendo os lugares e objetos especiais que têm um papel fundamental para a compreensão da história da Terra (ProGEO, 2011). Por sua vez, Carcavilla et al. (2008, p. 3001) trazem uma abordagem ampla de geopatrimônio ao defini-lo enquanto "el conjunto de elementos geológicos que destacan por su valor científico, cultural o educativo". A relevância em conservar o geopatrimônio é dada por esses serem compostos, quase que exclusivamente, de elementos não renováveis, ou seja, uma vez perdidos não poderão ser reavidos numa escala de tempo histórica.

A geoconservação é entendida como o conjunto de medidas que permitem a conservação do patrimônio geológico de um determinado local. Brilha (2005, p. 117) expõe que a geoconservação está enquadrada no paradigma da sustentabilidade por ser a união de "ações que podem ser repetidas, por um tempo indefinido, tendo em consideração três eixos fundamentais: ambiental; [...] social e cultural [...]; econômico". A geoconservação apresenta diversos objetivos e estratégias passíveis de serem aplicadas. Pode ter foco em critérios científicos e de aspectos locais, como a conservação de um determinado afloramento que marca mudança de eras geológicas, ou, medidas de caráter socioeducativo e de maior amplitude, como a busca por uma consciência ambiental sistêmica por meio da inserção dos seus conhecimentos em atividades de educação ambiental.

\section{Inventário e Avaliação do Geossítio Trilha-Ubajara Araticum}

O geossítio Trilha Ubajara-Araticum compreende um caminho que liga as áreas elevadas do Glint da Ibiapaba à Depressão Sertaneja. Segundo Souza et al. (1979), a Ibiapaba constitui um relevo dissimétrico de caráter cuestiforme, com disposição geral no sentido norte-sul, com escarpamento contínuo, abrupto, bastante festonado e caimento gradativo para oeste. Em "termos estruturais, a escarpa da Ibiapaba compreende o rebordo leste da Bacia do Parnaíba. Este rebordo constitui um 'front' de declive superior a $35 \%$ que contrasta para leste com os terrenos rebaixados e aplainados da depressão sertaneja" (SOUZA et al., 1979, p. 82).

Mesmo que, morfologicamente, a designação de cuesta seja adequada à Ibiapaba, Moura-Fé (2017a, p. 1850) expõe que essa definição pode ser complementada devido a "particularidade no tocante aos seus contatos, os quais não são realizados com litologias sedimentares, como ocorre normalmente com as cuestas, mas sim, com litologias cristalinas, onde o conceito geomorfológico adequado para esse tipo de contato é glint”.

Entre os domínios do Glint da Ibiapaba e da Depressão Sertaneja desenvolve-se uma zona de transição topográfica descrita por Moura-Fé (2017b) como superfícies dissecadas do embasamento. Essas áreas passaram por processos de soerguimento em consonância com o Glint da Ibiapaba. Segundo o autor, as 
superfícies soerguidas dissecadas são caracterizadas por altitudes entre 228 e 487 m, sendo nesse domínio se encontra parte do geossítio.

A Depressão Sertaneja configura a unidade geomorfológica de maior expressão no Estado do Ceará, ocupando aproximadamente $70 \%$ do seu território. Segundo Lima et al. (2000), a Depressão Sertaneja dispõe-se nas periferias dos planaltos sedimentares ou embutidos entre esses e os maciços residuais cristalinos, apresentando cotas altimétricas abaixo dos $400 \mathrm{~m}$ e relevo, predominantemente, plano ou suave ondulado.

O caminho da Trilha Ubajara-Araticum é composto por calçamento rústico (grandes paralelepípedos de arenito) bastante erodido pelo uso e ações climáticas. O mesmo, apesar do desnível altimétrico, não apresenta grande declividade já que os sete quilômetros foram desenhados na forma de "zig-zag", especialmente nas áreas mais escarpadas, o que facilita o trânsito de pessoas e animais com cargas. Esse caminho foi instituído por populações locais como meio de ligação entre o distrito de Araticum e a sede municipal de Ubajara, configurando um bem histórico e cultural da região.

Atualmente, a trilha também é utilizada para práticas turísticas, sendo um dos cinco roteiros comercializados no âmbito do PNU. O roteiro turístico que passa pelo geossítio Trilha Ubajara-Araticum interliga o centro de visitação à Gruta de Ubajara, principal atrativo turístico da unidade de conservação. A mesma só pode ser realizada com a companhia de guias habilitados pela Cooperativa de Trabalho, Assistência ao Turismo e Prestação de Serviços Gerais, que atua junto à gestão do parque na prestação de serviços turísticos e de conservação.

Diferente do roteiro tradicional, o início do geossítio se dá nas coordenadas (UTM) 287837 Leste e $9575535 \mathrm{Sul}$, a $836 \mathrm{~m}$, e o ponto final nas coordenadas (UTM) 288878 Leste e 9576207 Sul, próximo a bifurcação para à Gruta de Ubajara, a $464 \mathrm{~m}$ de altitude. A diferença hipsométrica de $372 \mathrm{~m}$ confere uma variedade litológica e paisagística, sendo possível distinguir a disposição estratigráfica do Grupo Serra Grande e o contato com as rochas do Grupo Ubajara.

O geossítio Trilha Ubajara-Araticum está inserido no framework das zonas com coberturas cenozoicas, por estar disposto no degrau geomorfológico entre o Glint da Ibiapaba e a Depressão Sertaneja, abarcando tanto depósitos coluvionares quaternários, como afloramentos paleozoicos e neoproterozoicos (Figura 1). Essa categoria temática se estende no PNU como uma estreita linha que acompanha a porção leste da zona de escarpa, sendo uma área com declividade acentuada e presença de depósitos clásticos de diferentes tamanhos (areais, seixos, matacões e blocos extensos rolados).

Quanto à tipologia, o geossítio compreende uma área complexa (FUERTEZ-GUTIÉRREZ; FERNÁNDES-MARTINEZ, 2010), expondo diferentes elementos da geodiversidade com potencial para o desenvolvimento de pesquisas científicas, ações educativas e de interpretação ambiental. Apresenta 32,4 ha, sendo o seu perímetro definido pelo limite oeste do PNU, o curso do rio das Minas e áreas de amortecimento de 75 a $100 \mathrm{~m}$ dos principais pontos de interesse. O geossítio apresenta caráter sedimentar, metamórfico e paleoambiental. Para o melhor entendimento, os pontos de interesse serão tratados de forma individual.

O primeiro ponto de interesse está próximo ao início da trilha, nas coordenadas (UTM) 287899 Leste e 9575539 Sul, a $812 \mathrm{~m}$, ocorre o afloramento de um arenito consolidado, uniforme e com camadas bem definidas. É possível visualizar a homogeneidade dos grãos, a boa seleção e o acúmulo de óxido de ferro.

O segundo ponto está localizado nas coordenadas (UTM) 288017 Leste e 9575509 Sul, a 720 m de altitude, e é caracterizado pelo afloramento de um arenito de grão fino e uniforme (Figura 2A). Segundo a análise microscópica de material coletado no afloramento, o mesmo é caracterizado por quartzarenitos bem selecionados, com grãos muito finos com caulinita cristalizada paralelamente à direção da sedimentação, sendo a cimentação principal oriunda de minerais opacos, provavelmente óxidos (Figura 2A). Salienta-se que os afloramentos abordados até o momento se apresentam enquanto seções, com uma distribuição linear em forma de paredões rochosos. Os dois afloramentos compreendem diferentes fáceis da Formação Tianguá, unidade intermediária do Grupo Serra Grande (CPRM, 2014).

O Grupo Serra Grande é a primeira supersequência de deposição sedimentar da Bacia do Parnaíba, estando sobreposta ao embasamento cristalino (VAZ et al., 2007). Caputo e Lima (1984) expõem que no contexto da Bacia do Parnaíba a seção Serra Grande é uma das mais discutidas quanto à idade, subdivisões e ambiente de sedimentação, sendo desses autores a subdivisão atualmente aceita do grupo em formações Ipu, Tianguá e Jaicós. 


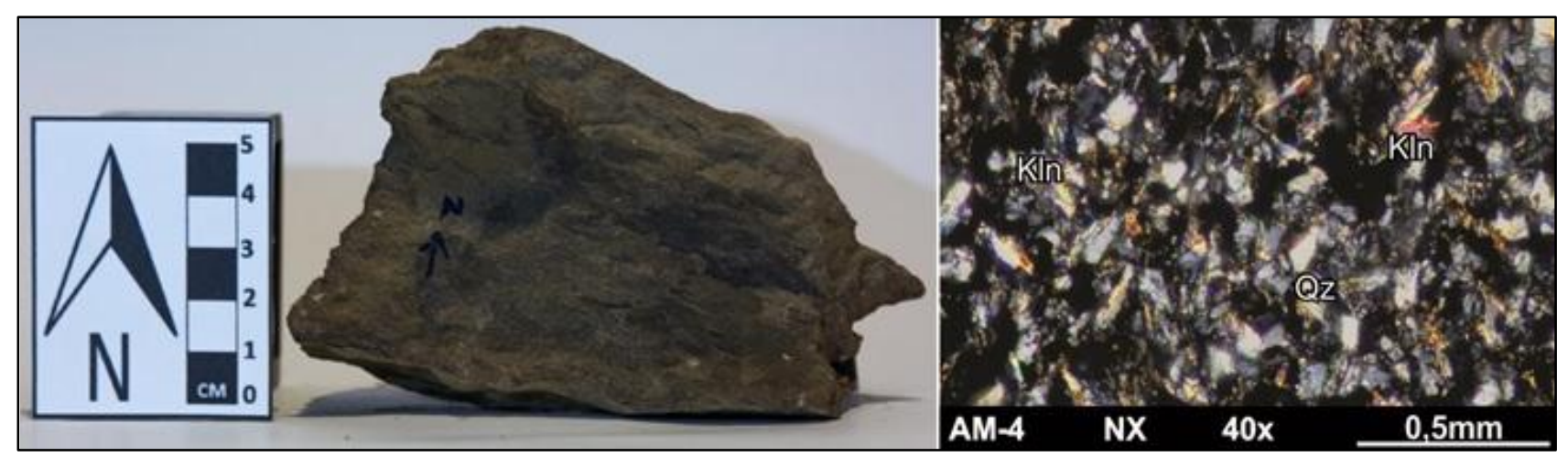

Figura 2: A) Detalhamento da amostra de rocha da Formação Tianguá. B) Fotomicrografia de Quartzarenito muito fino em microscópio petrográfico, com nicóis cruzados, mostrando os grãos de quartzo (Qz) do arcabouço, minerais opacos e caulinita (Kln). Fonte: Coleta e análise microscópica de autoria própria (2018).

A Formação Tianguá, que engloba os afloramentos descritos, é composta por folhelhos cinza-escuro (bioturbados, sideríticos e carbonáticos), arenitos cinza-claro (variando de fino a médio, feldspáticos), intercalações de siltitos e folhelhos cinza-escuros (bioturbados e micáceos) (GOÉS; FEIJÓ, 1994). Caputo e Lima (1984) subdividiram a Formação Tianguá em três membros, sendo: i) o primeiro composto por folhelho preto a cinza escuro, siderítico, bioturbado ou laminado, síltico; ii) por sua vez, o segundo compreende arenitos de granulometria fina a média, com intercalações de folhelho, feldspático, cinza esbranquiçado; iii) por fim, no terceiro membro estão presentes folhelhos e siltitos intercalados, cinza escuros a verdes, micáceos, sideríticos. A Formação Tianguá se dispõe de forma concordante com as formações Ipu e Jaicós (CAPUTO; LIMA, 1984). É apontada a idade de deposição eosiluriana, tendo como base estudo palinológicos e de macrofósseis, e ambiente de deposição marinho raso (GOÉS; FEIJÓ, 1994).

O terceiro ponto de interesse está localizado nas coordenadas (UTM) 288020 Leste e 9575669 Sul, a 705 m, e compreende a base da Cachoeira do Cafundó. O local dispõe de blocos rochosos onde é possível realizar explanações sobre os aspectos hidrográficos (capacidade de transporte), de evolução do relevo (queda de blocos e recuo erosivo da vertente) e orientação das camadas sedimentares. No local também é possível visualizar icnofósseis entre os blocos rochosos (Figura 3), ou seja, vestígios de atividades de um determinado organismo (animal ou vegetal) preservado em uma rocha. Viana et al. (2010) salientam a importância dos icnofósseis no entendimento paleoambiental e desenvolvem um trabalho sobre as tipologias encontradas no âmbito do Grupo Serra Grande.

Com base no trabalho citado infere-se que o registro encontrado compreende o icnogênero Planolites Nicholson, uma vez que segue as mesmas características, como o comprimento, largura, forma, disposição horizontal e preenchimento semelhante a rocha matriz. Porém, a definição da espécie presente carece de confirmação. Como os registros estão presentes em blocos rolados não é possível ter certeza de que ponto da escarpa os mesmos se deslocaram. Porém, como o contexto litológico local remete à Formação Tianguá, foi atribuída a idade siluriana.

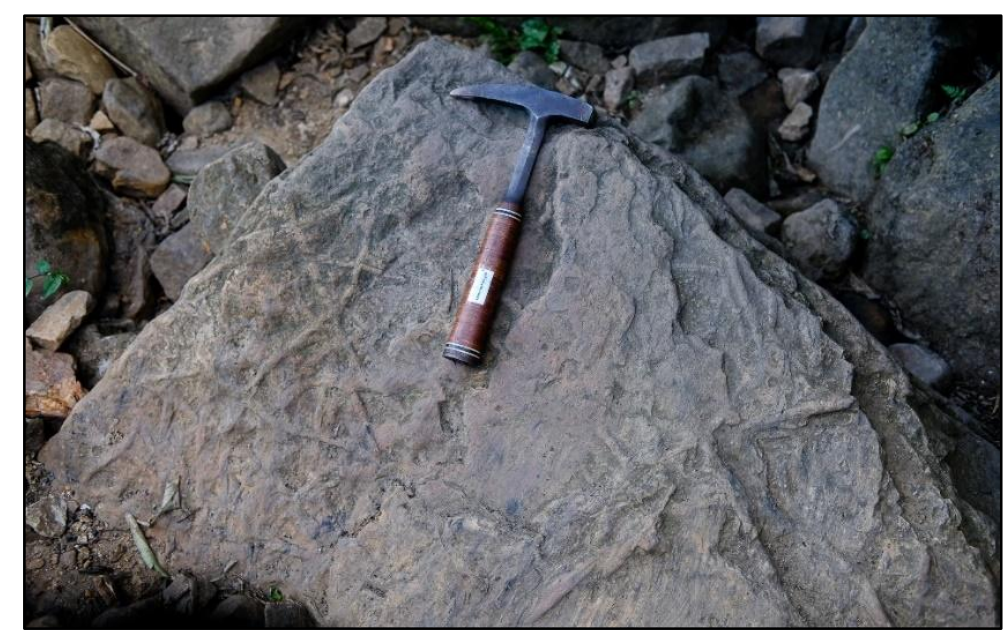

Figura 3: Icnofósseis presente em bloco rolado na base da Cachoeira do Cafundó. Fonte: Autoria própria (2017). 
O quarto ponto de interesse está localizado nas coordenadas (UTM) 288165 Leste e 9576003 Sul, a 677 $\mathrm{m}$ de altitude, sendo caracterizado pelo afloramento de um arenito mal selecionado com presença de camadas de seixos (Figura 4A). Segundo análise microscópica a amostra compreende um quartzarenito grosso moderadamente selecionado de empacotamento apertado e que apresenta como evento diagenético mais importante a cristalização secundária de quartzo (Figura 4B).

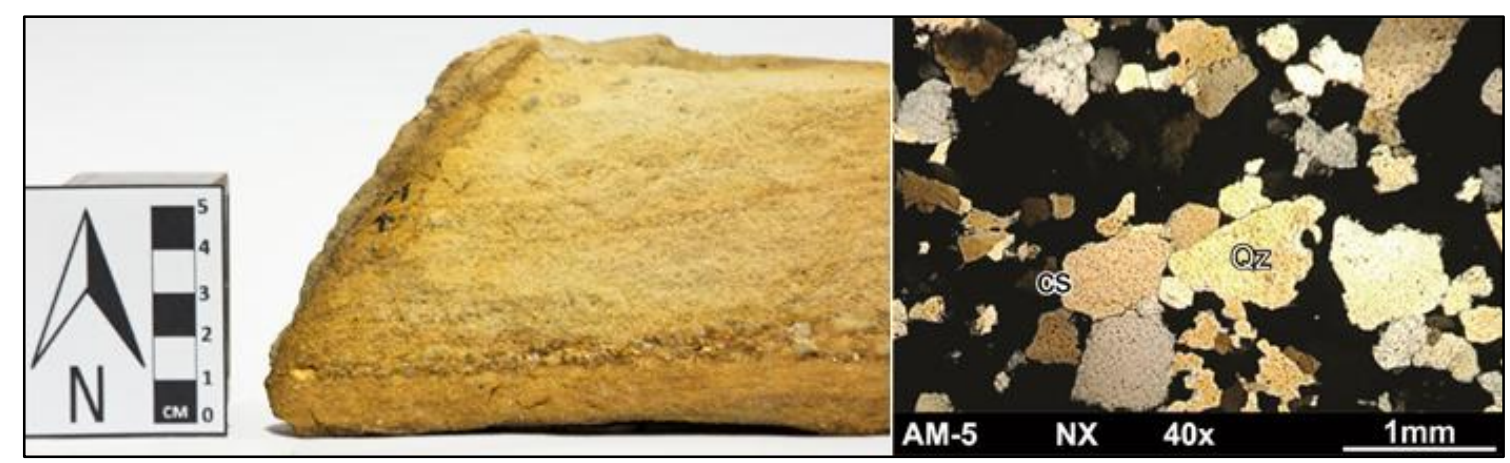

Figura 4: A) Amostra com camada de grãos grossos e seixos no arenito da Formação Tianguá. B) Fotomicrografia de Quartzarenito grosso, com crescimento secundário (cs) de quartzo (Qz). Fonte: Coleta e análise microscópica de autoria própria (2018).

A amostra do quarto ponto e os afloramentos correlatos, com presença de seixos e linhas de conglomerados, suscitam uma dúvida estratigráfica para a área, uma vez que segundo o mapeamento geológico em escala 1:100.000 (CPRM, 2014) não há afloramento da Formação Ipu (rochas basais do Grupo Serra Grande). Quando analisado a descrição da Formação Tianguá não há relato de fáceis com presença de conglomerados, porém, tal fato é comum na Formação Ipu (CAPUTO; LIMA, 1984), outro fato que corrobora ao questionamento é a disposição dessas rochas em porções menos elevadas e próximas ao contato com rochas do Grupo Ubajara, sendo a base do Grupo Serra Grande na área.

A Formação Ipu é a unidade basal do Grupo Serra Grande, sendo composta, principalmente, por arenitos, conglomerados e diamictitos. Caputo e Lima (1984, p. 742) sugerem que o ambiente de deposição desta Formação, tendo como base a distribuição e a correlação com formações equivalentes desde a costa nordeste do Brasil até o interior da Bacia do Parnaíba, deu-se "em leques glaciais e periglaciais (depósitos "sandur" e "out wash") em toda a área dos afloramentos atuais e deposição em leques deltaicos e frente de leque deltaico no interior da bacia, e marinho raso nas partes distais". A ausência de fósseis diagnósticos resultou em diferentes datações para a deposição da Formação Ipu, porém, a literatura tende a considerar que a sua gênese se deu no final do ordoviciano e o início do siluriano (CAPUTO; LIMA, 1984).

O quinto ponto de interesse é configurado por afloramentos de ardósias, rocha com baixo grau de metamorfismo, no leito do rio das Minas (Figura 5). O local se encontra nas coordenadas (UTM) 288444 Leste e $9575987 \mathrm{Sul}$, a $622 \mathrm{~m}$ de altitude, sendo o ponto de contato entre rochas sedimentares do Grupo Serra Grande e rochas metamórficas da Formação Caiçaras (Grupo Ubajara).

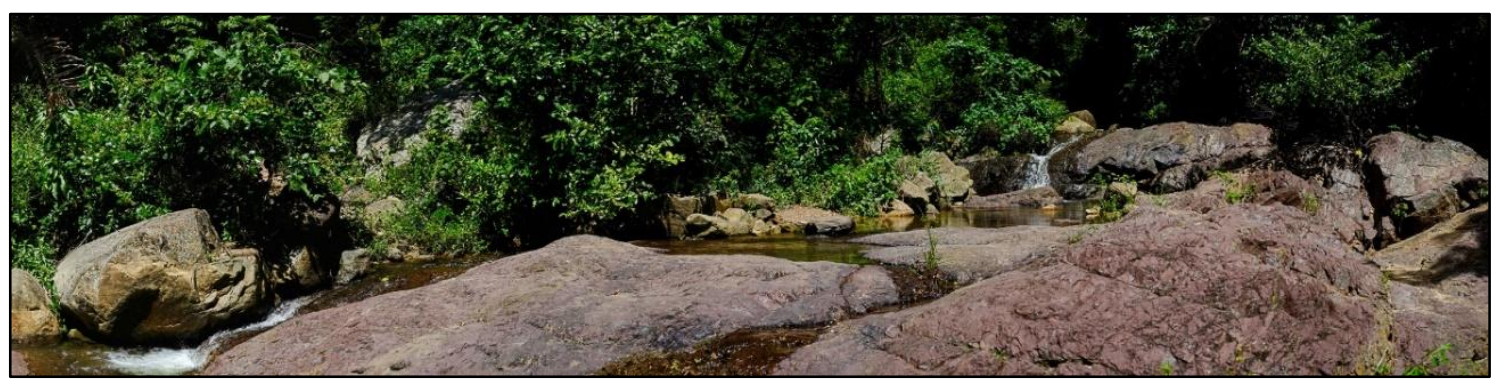

Figura 5: Afloramento de rochas da Formação Caiçaras no leito do rio das Minas. Fonte: Autoria própria (2017). 
A Formação Caiçaras, estratigraficamente, está na base da Formação Frecheirinha (composta principalmente por metacalcários), mas nesse afloramento está em cota mais elevada, remetendo a uma inversão de relevo. A inversão de relevo nesse caso é fruto da exposição, por meio de processos erosivos, de áreas dobradas e com acamalgamento formados por zonas de empurrões, que permitiu que a rocha da base sobrepunha à camada superior. Assim como ocorre com a Formação Ipu, o mapeamento geológico não descreve afloramentos da Formação Caiçaras na área.

No afloramento a rocha se apresenta bastante polida devido ao trabalho de erosão hídrica do rio das Minas (Figura 5). Macroscopicamente, nota-se que a mesma apresenta caráter maciço, sem lineamentos de minerais aparentes e a coloração de um vermelho escuro que remete ao processo de oxidação (Figura 6A). Microscopicamente, a amostra compreende uma ardósia, com laminações paralelas e porosidade de encolhimento (Figura 6B).

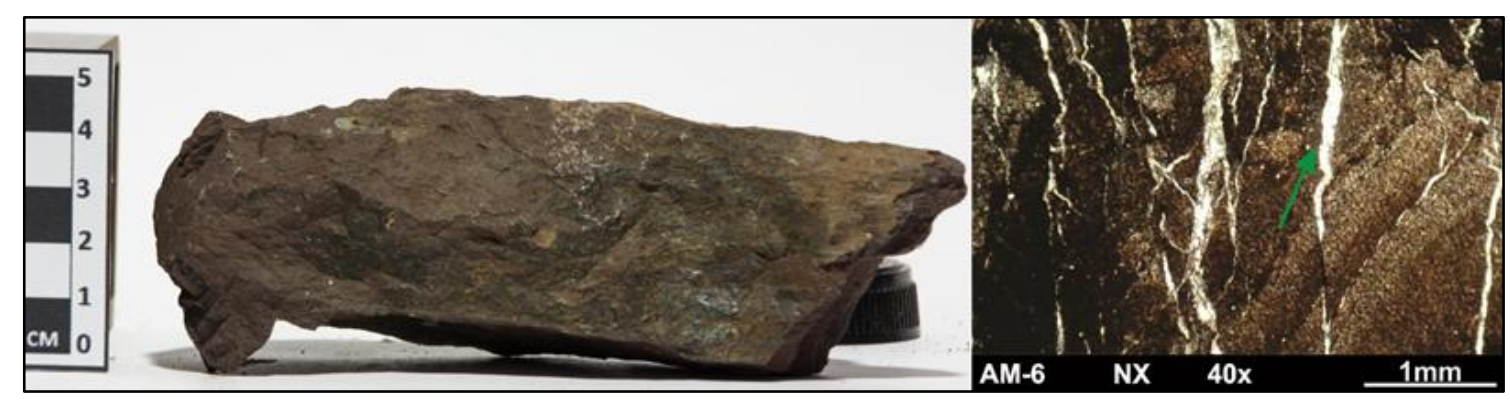

Figura 6: A) Amostra de ardósia coletada no Rio das Minas. B) Ardósia com porosidade de encolhimento (seta verde) em microscópio petrográfico, nicóis cruzados. Fonte: Coleta e análise microscópica de autoria própria (2018).

É válido pontuar que o Grupo Ubajara é uma sequência vulcano-sedimentar plataformal de idade neoproterozoica (650-850 Ma). É composto da base para o topo pelas formações Trapiá (metarenitos e metaconglomerados), Caiçaras (ardósias, metasiltitos e metarenitos), Frecheirinha (metacalcário, metasiltitos e metarenitos) e Coreaú (metarenitos e metapelitos) (CAVALCANTE et al., 1993; CPRM, 2014). A Formação Caiçaras apresenta ambiente de formação sedimentar marinho raso, é composta por ardósias vermelhas a roxo-avermelhadas, oriundas de metamorfização incipiente de rocha sedimentar argilosa, com intercalações de quartzitos frequentemente cristalizados e cortados por veios de sílica (CAVALCANTE et al., 1993). As rochas da Formação Frecheirinha também tiveram sua gênese em ambientes marinho raso, as principais litologias encontradas são metacalcários de granulação fina, de coloração preta, cinza azulada, cinza escura e mais raramente creme e rósea. Os metacalcários apresentam estratificação plano-paralela e laminação rítmica, são bastante impuros e com intercalações eventuais de delgados leitos margosos, metasiltitos e quartzitos escuros (CPRM, 2014). São nas rochas dessa formação que se desenvolve a província espeleológica de Ubajara.

O sexto ponto de interesse está localizado no final da trilha, nas coordenadas centrais (UTM) Leste 288878 e Sul 9576207, cota de 464 m. É caracterizado pela exposição de feições exocársticas do Morro de Ubajara, esculpido em rochas da Formação Frecheirinha e onde se desenvolve a Gruta de Ubajara, maior caverna do estado do Ceará com $1.120 \mathrm{~m}$ de dutos mapeados. O formato cônico de fácil distinção remete à um clássico cone cárstico, bem como as paredes externas que compreendem um expressivo campo de lapiás. As lapiás presente apresentam características típicas de rillenkarren, uma vez que são compostas por canais com poucos centímetros de largura e profundidade, mas com disposição paralela, seguindo a direção da maior inclinação do afloramento (PILÓ, 2000).

Foram coletadas e analisadas microscopicamente duas amostras retiradas dos afloramentos do Morro de Ubajara, uma nas coordenadas (UTM) Leste 289006 e Sul 9576056, na cota de $500 \mathrm{~m}$, compreende um metacalcário, totalmente recristalizada em calcita blocosa e granular (Figura 7A, B). A outra foi coletada nas coordenadas (UTM) Leste 288994 e Sul 9576079, cota de 507 m, compreende uma metacalcário do tipo mudstone com recristalização microcristalina da matriz micrítica, com sombras de recristalização em torno de clastos de quartzo (Figura 8A, B). 


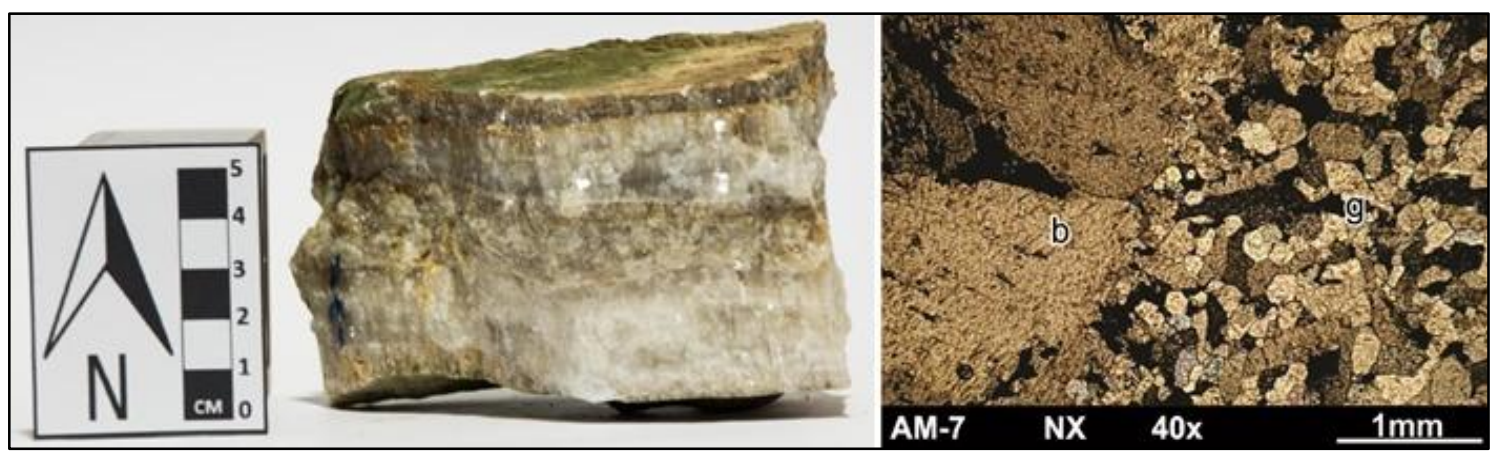

Figura 7: A) Metacalcário retirado do Morro de Ubajara. B) Fotomicrografia dos metacalcários da Formação Frecheirinha, exibindo recristalização em calcita blocosa (b), granular (g). Fonte: Coleta e análise microscópica de autoria própria (2018).

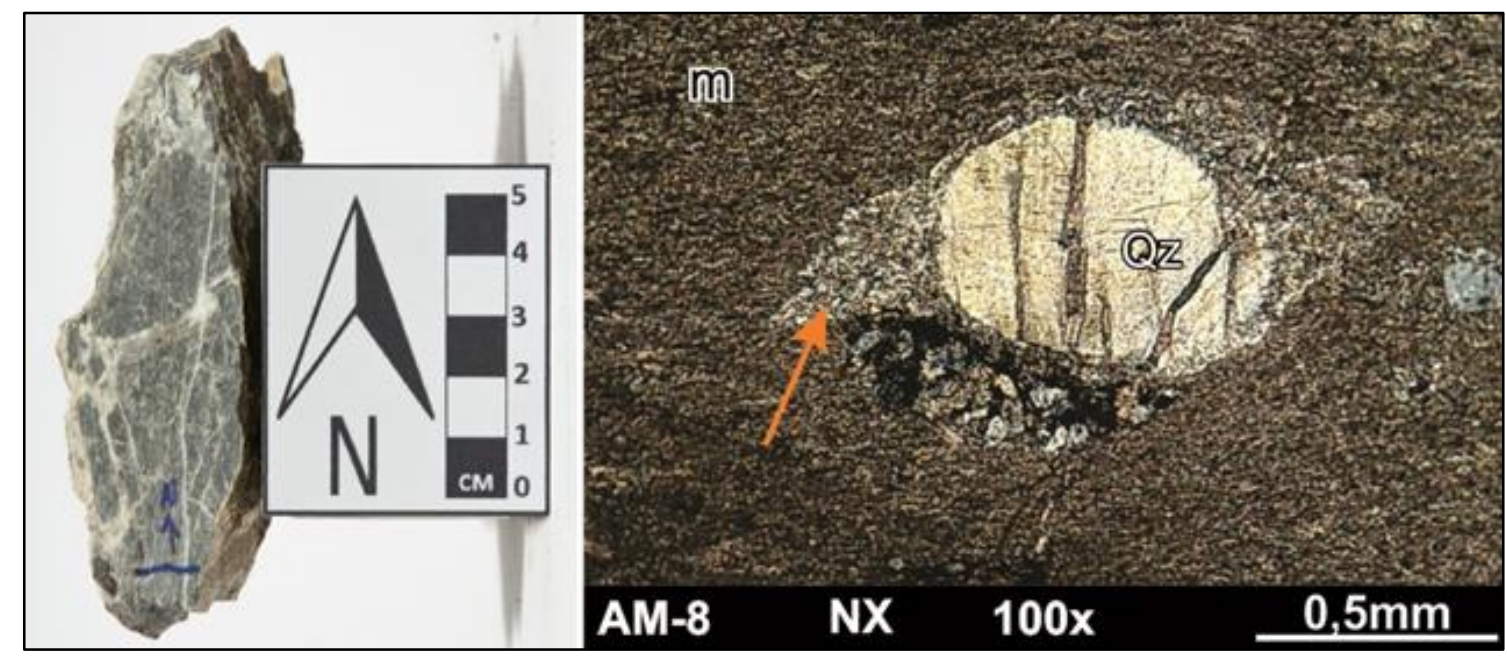

Figura 8: A) Metacalcário retirado do Morro de Ubajara. B) Fotomicrografia dos metacalcários da Formação Frecheirinha, exibindo microcristalina (m) e estrutura de sombra de pressão (seta laranja) em torno de clasto de quartzo (Qz). Fonte: Coleta e análise microscópica de autoria própria (2018).

Com base nas informações obtidas no inventário foi realizada a avaliação do valor científico, turístico e educativo do geossítio Trilha Ubajara-Araticum. Quanto ao valor científico, o geossítio obteve uma alta pontuação, nomeadamente de 290 pontos (Tabela 1). Esse dado confere ao local o status de geossítio segundo a metodologia do GEOSSIT, ou seja, o considera enquanto espaço de importância científica relevante ao entendimento da evolução geológica nacional. $\mathrm{O}$ alto potencial científico advém da diversidade de temáticas abordadas, que parte dos aspectos petrológico, geomorfológico, pedológico, hidrológico e paleontológico/paleoambiental. Outro fato é o seu papel enquanto um retrato estratigráfico da porção leste da Bacia do Parnaíba, com afloramentos bem delimitados e de fácil visualização de diferentes formações geológicas e zonas de contato.

Tabela 1:Avaliação quantitativa do Geossítio Trilha Ubajara-Araticum

\begin{tabular}{|c|c|c|c|}
\hline \multicolumn{4}{|c|}{ Valor Científico } \\
\hline Parâmetro & Peso & Descrição e Valor Obtido no Parâmetro & \\
\hline Representatividade & 30 & $\begin{array}{l}\text { Melhor exemplo na área para ilustrar elementos ou processos } \\
\text { relacionados com a área temática em questão }\end{array}$ & 4 \\
\hline Integridade & 15 & Os principais elementos geológicos estão bem preservados & 4 \\
\hline Diversidade Geológica & 5 & $\begin{array}{l}\text { Local de com } 5 \text { ou mais tipos diferentes de aspectos geológicos com } \\
\text { relevância científica }\end{array}$ & 4 \\
\hline Raridade & 15 & O local é a única ocorrência desse tipo na área de estudo & 4 \\
\hline Limitações de Uso & 10 & $\begin{array}{l}\text { É possível fazer trabalhos de campo e amostragem depois de ultrapassar } \\
\text { as limitação existentes }\end{array}$ & 2 \\
\hline Local Tipo & 20 & Nâo se aplica & 0 \\
\hline Conhecimento Científico & 5 & Existem artigos científicos sobre o local em revistas científicas & 2 \\
\hline
\end{tabular}




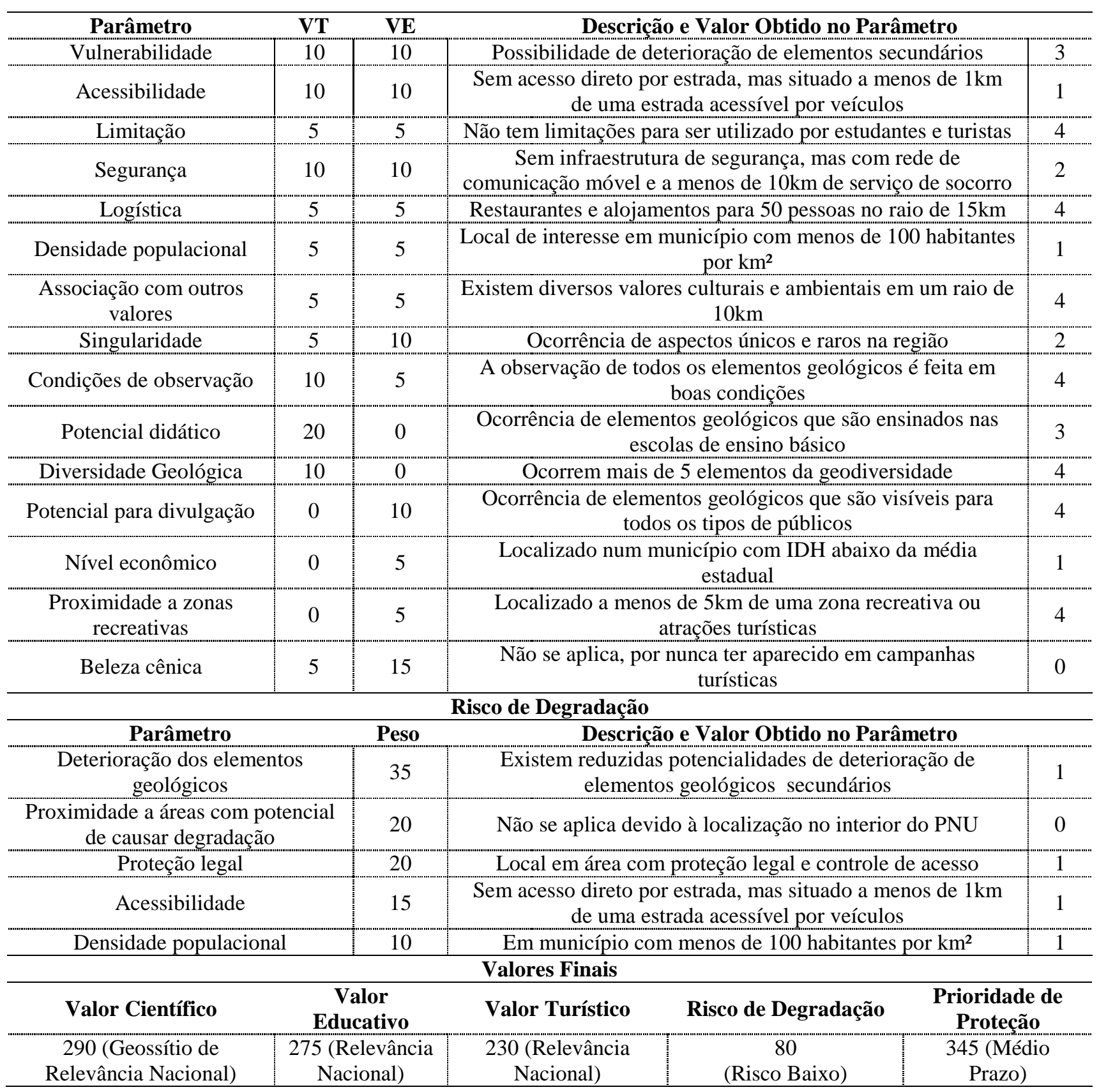

Fonte: Autoria própria

No que concerne ao valor educativo o geossítio obteve 275 pontos, configurando um local de relevância nacional (Tabela 1). Alguns critérios como a diversidade de elementos abordados, ausência de limitação de uso e associação com valores ecológicos e culturais contribuíram para o acréscimo da nota obtida. Por sua vez, parâmetros como o de acessibilidade obteve nota mínima e o potencial educativo que não alcançou a nota máxima devido à complexidade dos temas abordados. Salienta-se que os temas presentes partem de uma descrição geológica e geomorfológica mais aprofundada, sendo necessário algum conhecimento prévio sobre conceitos e temas das geociências ou uma capacidade de abstração para o entendimento dos processos, o que dificulta a utilização do geossítio para os anos inicias do ensino fundamental, por exemplo, mas o torna propício para ações junto ao ensino médio e, especialmente, para o ensino superior.

O menor valor de uso alcançado foi o referente ao turístico, com 230 pontos (Tabela 1). Apesar dos elementos de interesse, diversidade de paisagens e boa visualização, a acessibilidade é uma problemática, bem como o fato de não ser utilizado em campanhas turísticas (critério beleza cênica) e não dispor de aparatos de segurança. Mesmo com os entraves para uma melhor pontuação, o geossítio apresenta relevância nacional no valor turístico, demonstrando a sua vocação para o desenvolvimento de atividades relacionadas ao turismo científico, de natureza e ao geoturismo.

O risco de degradação do geossítio é baixo, tendo alcançando o valor de 80 pontos neste parâmetro (Tabela 1). A reduzida potencialidade de deterioração dos elementos geológicos de interesse, o fato de a área 
estar localizada no contexto de uma unidade de conservação e apresentar limitação de acesso contribuíram para o baixo índice. Quanto ao critério de prioridade de proteção, que mescla as potencialidades e as vulnerabilidades, o geossítio apresenta necessidade de ações a médio prazo, especialmente devido ao baixo risco de degradação.

A etapa de avaliação é de fundamental importância para distinguir os geossítios dentro de um contexto, servindo como método de seleção e de comparação de locais no âmbito da gestão do patrimônio geológico. Dessa forma, realizar a avaliação de apenas um geossítio perde o sentido, uma vez que não há outras referências para efetivar a comparação. Porém, como salientado, o presente trabalho está inserido no âmbito do inventário e avaliação do patrimônio geológico do PNU, onde se inventariaram onze geossítios e sítios da geodiversidade (Tabela 2).

Tabela 2: Comparação dos valores de uso do geossítio Trilha Ubajara-Araticum com os demais geossítios e sítios da geodiversidade (SG) do Parque Nacional de Ubajara

\begin{tabular}{|c|c|c|c|c|c|}
\hline & $\begin{array}{c}\text { Valor } \\
\text { Científico }\end{array}$ & $\begin{array}{c}\text { Valor } \\
\text { Educativo }\end{array}$ & $\begin{array}{c}\text { Valor } \\
\text { Turístico } \\
\end{array}$ & $\begin{array}{c}\text { Risco de } \\
\text { Degradação }\end{array}$ & $\begin{array}{c}\text { Ponderação } \\
\text { Final }\end{array}$ \\
\hline $\begin{array}{l}\text { Geossítio Trilha Ubajara- } \\
\text { Araticum }\end{array}$ & $\begin{array}{l}1^{\circ} \text { colocado } \\
(290 \text { pontos })\end{array}$ & $\begin{array}{l}11^{\circ} \text { colocado } \\
\text { (275 pontos) }\end{array}$ & $\begin{array}{l}9^{\circ} \text { colocado } \\
\text { ( } 230 \text { pontos) }\end{array}$ & $\begin{array}{l}3^{\circ} \text { colocado } \\
(80 \text { pontos })\end{array}$ & $\begin{array}{l}6^{\circ} \text { Lugar } \\
(24 \text { pontos })\end{array}$ \\
\hline SG Sítio do Bosco & $\begin{array}{l}10^{\circ} \text { colocado } \\
(185 \text { pontos })\end{array}$ & $\begin{array}{l}5^{\circ} \text { colocado } \\
\text { (325 pontos) }\end{array}$ & $\begin{array}{l}5^{\circ} \text { colocado } \\
(265 \text { pontos })\end{array}$ & $\begin{array}{l}8^{\circ} \text { colocado } \\
\text { (155 pontos })\end{array}$ & $\begin{array}{l}8^{\circ} \text { Lugar } \\
\text { (28 pontos) }\end{array}$ \\
\hline Geossítio Paredões de Janeiro & $\begin{array}{l}3^{\circ} \text { colocado } \\
\text { (285 pontos) }\end{array}$ & $\begin{array}{l}8^{\circ} \text { colocado } \\
\text { (305 pontos) }\end{array}$ & $\begin{array}{l}6^{\circ} \text { colocado } \\
(255 \text { pontos })\end{array}$ & $\begin{array}{l}6^{\circ} \text { colocado } \\
(120 \text { pontos })\end{array}$ & $\begin{array}{l}5^{\circ} \text { Lugar } \\
\text { (23 pontos) }\end{array}$ \\
\hline Geossítio Cachoeira do Pinga & $\begin{array}{l}5^{\circ} \text { colocado } \\
\text { (225 pontos) }\end{array}$ & $\begin{array}{l}7^{\circ} \text { colocado } \\
\text { (310 pontos) }\end{array}$ & $\begin{array}{l}8^{\circ} \text { colocado } \\
(240 \text { pontos })\end{array}$ & $\begin{array}{l}7^{\circ} \text { colocado } \\
\text { (135 pontos) }\end{array}$ & $\begin{array}{l}7^{\circ} \text { Lugar } \\
(27 \text { pontos })\end{array}$ \\
\hline Geossítio Mirante da Gameleira & $\begin{array}{l}4^{\circ} \text { colocado } \\
(260 \text { pontos })\end{array}$ & $\begin{array}{l}3^{\circ} \text { colocado } \\
\text { (340 pontos) }\end{array}$ & $\begin{array}{l}2^{\circ} \text { colocado } \\
(300 \text { pontos })\end{array}$ & $\begin{array}{l}1^{\circ} \text { colocado } \\
(45 \text { pontos })\end{array}$ & $\begin{array}{l}1^{\circ} \text { Lugar } \\
\text { (10 pontos) }\end{array}$ \\
\hline Geossítio Mirante do Pendurado & $\begin{array}{l}7^{\circ} \text { colocado } \\
\text { (200 pontos) }\end{array}$ & $\begin{array}{l}1^{\circ} \text { colocado } \\
\text { (355 pontos) }\end{array}$ & $\begin{array}{l}4^{\circ} \text { colocado } \\
(290 \text { pontos })\end{array}$ & $\begin{array}{l}4^{\circ} \text { colocado } \\
\text { (90 pontos) }\end{array}$ & $\begin{array}{l}4^{\circ} \text { Lugar } \\
\text { (16 pontos) }\end{array}$ \\
\hline Geossítio Circuito das Cachoeiras & $\begin{array}{l}7^{\circ} \text { colocado } \\
\text { (200 pontos) }\end{array}$ & $\begin{array}{l}3^{\circ} \text { colocado } \\
\text { (340 pontos) }\end{array}$ & $\begin{array}{l}2^{\circ} \text { colocado } \\
(300 \text { pontos })\end{array}$ & $\begin{array}{l}1^{\circ} \text { colocado } \\
(45 \text { pontos }\end{array}$ & $\begin{array}{l}2^{\circ} \text { Lugar } \\
(13 \text { pontos })\end{array}$ \\
\hline SG Cachoeira do Pinguruta & $\begin{array}{l}9^{\circ} \text { colocado } \\
\text { (195 pontos) }\end{array}$ & $\begin{array}{l}9^{\circ} \text { colocado } \\
(300 \text { pontos })\end{array}$ & $\begin{array}{l}9^{\circ} \text { colocado } \\
(230 \text { pontos })\end{array}$ & $\begin{array}{l}5^{\circ} \text { colocado } \\
\text { (105 pontos })\end{array}$ & $\begin{array}{l}9^{\circ} \text { Lugar } \\
\text { (32 pontos) }\end{array}$ \\
\hline Geossítio Cachoeira do Pajé & $\begin{array}{l}6^{\circ} \text { colocado } \\
(205 \text { pontos })\end{array}$ & $\begin{array}{l}10^{\circ} \text { colocado } \\
\text { (280 pontos) }\end{array}$ & $\begin{array}{l}11^{\circ} \text { colocado } \\
\text { (220 pontos) }\end{array}$ & $\begin{array}{l}10^{\circ} \text { colocado } \\
(235 \text { pontos })\end{array}$ & $\begin{array}{l}11^{\circ} \text { Lugar } \\
(37 \text { pontos) }\end{array}$ \\
\hline Geossítio Gruta de Ubajara & $\begin{array}{l}1^{\circ} \text { colocado } \\
(290 \text { pontos })\end{array}$ & $\begin{array}{l}2^{\circ} \text { colocado } \\
(345 \text { pontos })\end{array}$ & $\begin{array}{l}1^{\circ} \text { colocado } \\
\text { (310 pontos) }\end{array}$ & $\begin{array}{l}9^{\circ} \text { colocado } \\
(200 \text { pontos })\end{array}$ & $\begin{array}{l}2^{\circ} \text { Lugar } \\
(13 \text { pontos })\end{array}$ \\
\hline SG Furnas de Araticum & $\begin{array}{l}10^{\circ} \text { colocado } \\
(185 \text { pontos })\end{array}$ & $\begin{array}{l}6^{\circ} \text { colocado } \\
(315 \text { pontos })\end{array}$ & $\begin{array}{l}7^{\circ} \text { colocado } \\
(250 \text { pontos })\end{array}$ & $\begin{array}{l}11^{\circ} \text { colocado } \\
(335 \text { pontos })\end{array}$ & $\begin{array}{l}10^{\circ} \text { lugar } \\
(34 \text { pontos) }\end{array}$ \\
\hline
\end{tabular}

Fonte: Autoria própria

Nesse contexto, é apresentada na Tabela 2 a posição do geossítio Trilha Ubajara-Araticum no contexto da área de análise. Esse exercício de comparação lista as colocações de acordo o parâmetro avaliativo, resultando em uma ponderação que apresenta como lógica a soma das colocações dos valores de uso $\left(1^{\circ}\right.$ colocado $=1$ ponto, $2^{\circ}$ colocado $=2$ pontos, assim sucessivamente), sendo que quanto menor a pontuação final melhor o resultado. É possível visualizar que o geossítio Trilha Ubajara-Araticum se destacou como o de maior valor científico, juntamente com o geossítio Gruta de Ubajara, sendo um espaço voltado à pesquisa científica (Tabela 2). Nos demais critérios de uso, quando observada a comparação, o geossítio não aparece em boas colocações, sendo o último colocado no que tange ao potencial educativo e o penúltimo quanto ao valor turístico. Todavia, salienta-se que o geossítio Trilha Ubajara-Araticum apresenta relevância nacional em todos os critérios, sendo então um espaço propício para a realização dessas duas atividades.

\section{Valorização e divulgação do geossítio Trilha Ubajara-Araticum}

As etapas de valorização e divulgação do patrimônio geológico são, no contexto das estratégias de geoconservação, os momentos de maior proximidade entre os pesquisadores, os órgãos gestores e o público. É nessa fase que os dados obtidos são adaptados à uma linguagem passível de entendimento fora do meio acadêmico, configurando ações aplicadas à gestão e à conservação ambiental. Essas duas etapas apresentam particularidades, especialmente porque uma pensa o interior do geossítio, enquanto a outra tem como foco a percepção e a ampliação da visibilidade do mesmo. 
As medidas de valorização compreendem o conjunto de ações relacionadas à informação e à interpretação dos geossítios, possibilitando que os visitantes reconheçam os seus valores. As propostas de valorização devem partir de ações de contexto local, compreendendo a busca pela tradução do ambiente para uma linguagem passível de entendimento pelo público alvo. As medidas de valorização devem preceder a etapa de divulgação do patrimônio geológico, sendo responsáveis pela construção de um aparato técnico e do planejamento necessário para suportar o aumento na visitação e a melhoria das experiências dos visitantes.

Algumas características teóricas e práticas intrínsecas às geociências devem ser levadas em consideração para que a valorização do patrimônio geológico cumpra com as suas funções. Dentre elas, compreender as diferentes magnitudes físicas que os elementos geológicos apresentam, o fato dos processos serem explicado no tempo geológico e não histórico, a diversidade de âmbitos geográficos, a ausência de apelo cênicos em diversos sítios de relevância científica e a necessidade de abstração para o entendimento dos processos. Cabe então, na etapa de valorização, mesmo diante dos obstáculos apresentados, a formulação de maneiras que permitam "aprovechar el alto potencial narrativo de la Geología, ya que muchos afloramientos cuentan una historia y crean un contexto que da significado a los datos científicos y a la investigación" (CARCAVILLA et al., 2010, p. 96).

Quanto à divulgação do patrimônio geológico, Brilha (2005, p. 109) aponta que "pode ser efetuada por intermédio de ações específicas ou em conjugação com ações de divulgação dos patrimônios natural e cultural", mas ela deve seguir, inevitavelmente, quatro princípios básicos da comunicação: captar a atenção do destinatário, tornar a informação agradável, tornar a comunicação relevante para o público e estruturar a comunicação.

Nesse contexto, foram construídas propostas de valorização e divulgação para o geossítio Trilha UbajaraAraticum, tendo como ponto de partida as suas potencialidades científicas, educativas e turísticas. As propostas buscam o aproveitamento da história, geologia e cultura, para construir uma narrativa em prol da conservação ambiental e popularização do conhecimento geológico. Entretanto, as medidas não objetivam a resolução de todos os questionamentos sobre os aspectos geológicos que possam surgir, mas sim, de uma forma não exaustiva, despertar a curiosidade dos visitantes tendo como embasamento técnicas de interpretação ambiental e geocomunicação.

Como estratégia de valorização do geossítio Trilha Ubajara-Araticum é proposta a confecção de um painel interpretativo que aborda o seu potencial estratigráfico. O título do painel interpretativo é "Que tal ser geólogo por um dia?", abaixo do título há uma apresentação sucinta do geossítio e é lançado um desafio aos visitantes, a identificação dos diferentes tipos de rocha que afloram no geossítio (Figura 9).

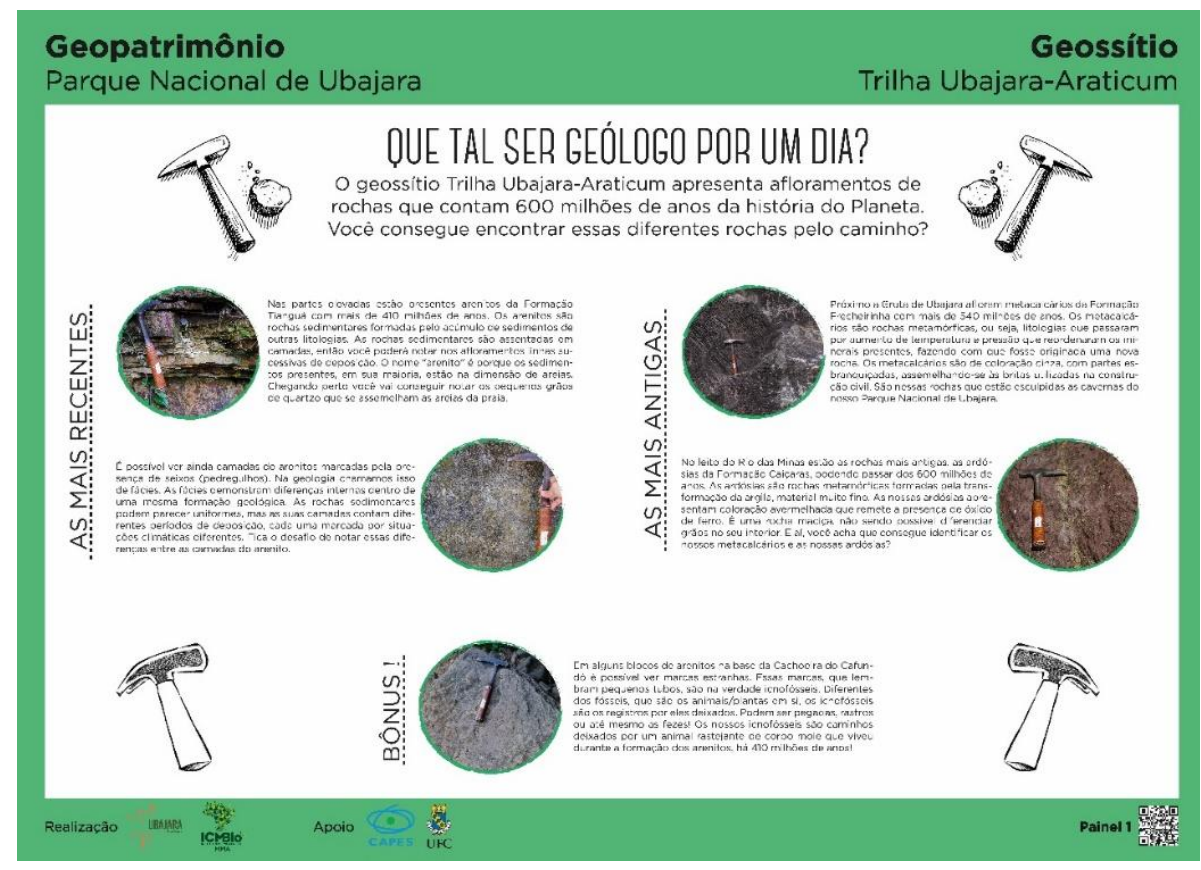

Figura 9: Painel interpretativo do geossítio Trilha Ubajara-Araticum. Fonte: Autoria própria.

O corpo do painel é composto por imagens e textos sobre as três litologias presentes (arenito, ardósia e metacalcário) e a identificação dos icnofósseis nos blocos da base da Cachoeira do Cafundó (Quadro 1). 
Quadro 1: Texto presente no painel interpretativo do geossítio Trilha Ubajara-Araticum. QUE TAL SER GEÓLOGO POR UM DIA?

O geossítio Trilha Ubajara-Araticum apresenta afloramentos de rochas que contam 600 milhões de anos da história do Planeta. Você consegue encontrar essas diferentes rochas pelo caminho?

\section{AS MAIS RECENTES}

Nas partes elevadas estão presentes arenitos da Formação Tianguá com mais de 410 milhões de anos. Os arenitos são rochas sedimentares formadas pelo acúmulo de sedimentos de outras litologias. As rochas sedimentares são assentadas em camadas, então você poderá notar nos afloramentos linhas sucessivas de deposição. O nome "arenito" é porque os sedimentos presentes, em sua maioria, estão na dimensão de areias. Chegando perto você vai conseguir notar os pequenos grãos de quartzo que se assemelham as areias da praia.

É possível ver ainda camadas de arenitos marcadas pela presença de seixos (pedregulhos). $\mathrm{Na}$ geologia chamamos isso de fácies. As fácies demonstram diferenças internas dentro de uma mesma formação geológica. As rochas sedimentares podem parecer uniformes, mas as suas camadas contam diferentes períodos de deposição, cada uma marcada por situações climáticas diferentes. Fica o desafio de notar essas diferenças entre as camadas do arenito.

\section{AS MAIS ANTIGAS}

Próximo a Gruta de Ubajara afloram metacalcários da Formação Frecheirinha com mais de 540 milhões de anos. Os metacalcários são rochas metamórficas, ou seja, litologias que passaram por aumento de temperatura e pressão que reordenaram os minerais presentes, fazendo com que fosse originada uma nova rocha. Os metacalcários são de coloração cinza, com partes esbranquiçadas, assemelhando-se às britas utilizadas na construção civil. São nessas rochas que estão esculpidas as cavernas do nosso Parque Nacional de Ubajara.

No leito do Rio das Minas estão as rochas mais antigas, as ardósias da Formação Caiçaras, podendo passar dos 600 milhões de anos. As ardósias são rochas metamórficas formadas pela transformação da argila, material muito fino. As nossas ardósias apresentam coloração avermelhada que remete a presença de óxido de ferro. É uma rocha maciça, não sendo possível diferenciar grãos no seu interior. E aí, você acha que consegue identificar os nossos metacalcários e as nossas ardósias?

\section{BÔNUS!}

Em alguns blocos de arenitos na base da Cachoeira do Cafundó é possível ver marcas estranhas. Essas marcas, que lembram pequenos tubos, são na verdade icnofósseis. Diferentes dos fósseis, que são os animais/plantas em si, os icnofósseis são os registros por eles deixados. Podem ser pegadas, rastros ou até mesmo as fezes! Os nossos icnofósseis são caminhos deixados por um animal rastejante de corpo mole que viveu durante a formação dos arenitos, há 410 milhões de anos!

Fonte: Autoria própria.

A linguagem utilizada no painel é simplificada, tendo-se procurado a substituição de termos técnicos por vocábulos do cotidiano, mas sem prejudicar a capacidade informativa. Alguns termos específicos das geociências como "rocha sedimentar" ou "rocha metamórfica" são utilizados, mas acompanhados de uma explicação sucinta do processo de formação. Na construção do painel interpretativo foi buscado o balanço entre os textos, as imagens e os espaços em branco.

É sugerido que o painel esteja localizado no começo do geossítio. Quanto às questões técnicas é proposto que o painel apresente $105 \mathrm{~cm}$ de comprimento por $75 \mathrm{~cm}$ de altura, sendo colocado no formato de mesa. A sua base pode ser construída com rochas da região, arenitos silicificados ou ardósias, por apresentarem boa resistência aos agentes intempéricos, ou mesmo madeira, que apesar de não apresentar a mesma resistência, configura uma opção durável e com preço acessível. Propõe-se ainda a utilização de acrílico ou policarbonato para reverter a impressão tornando-o mais durável, uma vez que esses materiais são resistentes a variações de temperaturas e ao impacto.

Como medidas de divulgação foram propostas a construção de um cartão postal, a integração do geossítio em um roteiro geoturístico e em um livro gráfico sobre o patrimônio geológico do Parque Nacional de Ubajara. Os cartões postais configuram uma estratégia de baixo custo e alta capacidade de propagação, sendo lembranças comuns em locais turísticos que alcançam um público variado e apresentam a capacidade de passar informação tanto para quem compra como para o destinatário.

É proposto que o cartão postal do geossítio apresente dimensão tradicional $(10 \mathrm{~cm}$ por $15 \mathrm{~cm})$. A parte frontal é composta por uma imagem da base da Cachoeira do Cafundó e o título "Parque Nacional de Ubajara" (Figura 10). No verso está localizada a frase de impacto "Descubra-se no Geopatrimônio do Parque Nacional de Ubajara" e espaços reservados para selo e escrita. No verso ainda apresenta a frase "série de postais sobre o Geopatrimônio do Parque Nacional de Ubajara", salientando que esse postal faz parte de uma série que contempla todos os geossítios inventariados no contexto da pesquisa de planejamento do patrimônio geológico local. 


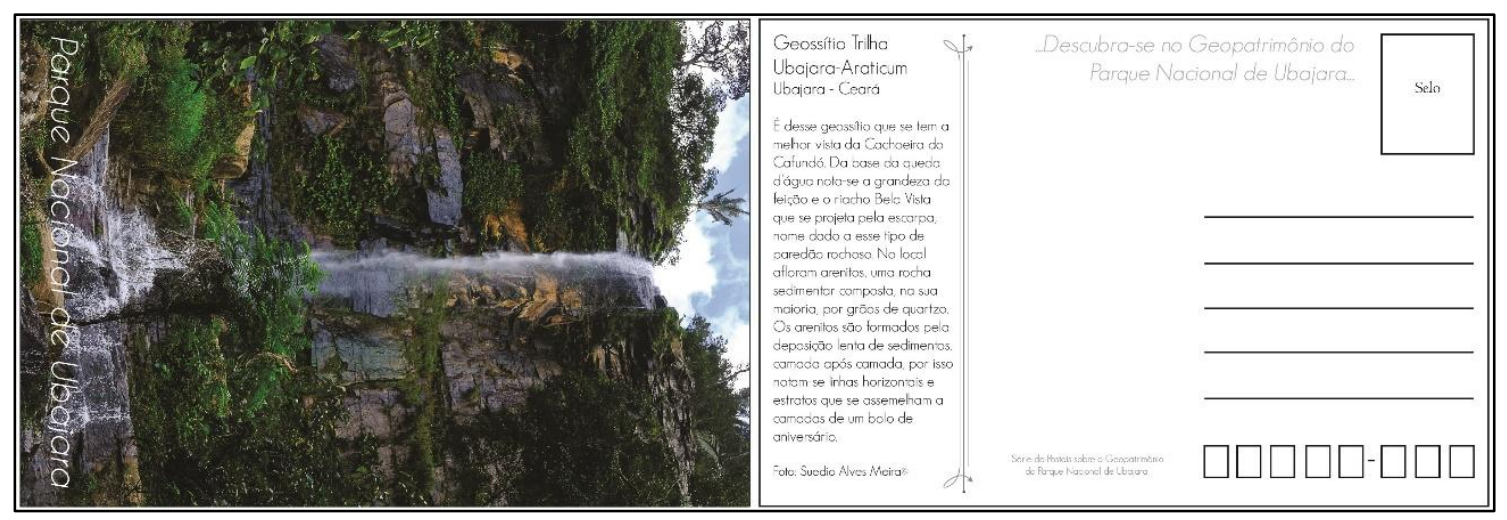

Figura 10: Cartão Postal geossítio Trilha Ubajara-Araticum $(10$ x $15 \mathrm{~cm})$. Fonte: Autoria própria.

A escolha da Cachoeira do Cafundó parte do apelo cênico e pela exposição das camadas de arenitos. O texto interpretativo está localizado no canto esquerdo logo abaixo do nome e cidade de localização do geossítio: "Deste geossítio, obtém-se a melhor vista da Cachoeira do Cafundó. Da base da queda d'água nota-se a grandeza da feição e o riacho Bela Vista que se projeta pela escarpa, nome dado a esse tipo de paredão rochoso. No local afloram arenitos, uma rocha sedimentar composta, na sua maioria, por grãos de quartzo. Os arenitos são formados pela deposição lenta de sedimentos, camada após camada, por isso notamse linhas horizontais e estratos que se assemelham a camadas de um bolo de aniversário.

O geossítio foi inserido em um roteiro geoturístico com foco nos aspectos científicos do Parque Nacional de Ubajara. O roteiro contempla os onze geossítios inventariados no projeto de pesquisa que o presente trabalho integra e foi construído para um público que busca conhecimento específico sobre o patrimônio geológico do PNU, integrando geossítios que abordam temas de maior complexidade. O roteiro é orientado a grupos educativos (especialmente para trabalho de campos de turmas do ensino superior relacionadas à vertente ambiental), grupos de adultos não-especializados, mas que procuram informações específicas, ou para grupo de pessoas aficionadas e especializadas.

O último instrumento de divulgação do geossítio é um livro gráfico que aborda o papel das fotografias na construção da imagem turística do Parque Nacional de Ubajara e atua como ferramenta de educação ambiental informal ao expor as potencialidades paisagísticas em consonância com textos interpretativos. Para o livro foram selecionados apenas os oito geossítios localizados no interior do PNU, já que um dos objetivos é a sua utilização enquanto material gráfico de divulgação pelo órgão gestor em feiras turísticas, encontros nacionais de unidades de conservação, dentre outros eventos.

O livro gráfico contém 24 páginas com dimensões de $20 \mathrm{~cm}$ de comprimento por $15 \mathrm{~cm}$ de altura. $\mathrm{O}$ título proposto foi "Parque Nacional de Ubajara: Geopatrimônio", remetendo ao conteúdo principal. Pretende-se que os leitores tenham contato com os conceitos de geodiversidade e de patrimônio geológico por meio de uma discussão simplificada e da exposição de exemplos presentes no Parque Nacional de Ubajara.

O geossítio Trilha Ubajara-Araticum ocupa duas páginas do livro gráfico, sendo representado por uma foto do afloramento de ardósia da Formação Caiçaras (Figura 5) e um texto sobre a estratigrafia do geossítio, sendo o mesmo: Seguindo uma trilha utilizada desde períodos remotos como ligação entre a serra e o sertão, o geossítio revela a base geológica que sustenta as formas de vida do Parque Nacional de Ubajara. Diferentes tipos de rochas afloram em seu percurso, que apresenta uma diferença de altitude de $400 \mathrm{~m}$. Nas áreas mais elevadas afloram os arenitos, nas porções inferiores predominam rochas metamórficas, como ardósias e metacalcários. Fica o desafio para você diferenciar essas litologias quando percorrer a trilha.

\section{Considerações Finais}

A proposta de geoconservação do geossítio Trilha Ubajara-Araticum demonstra como as temáticas da geodiversidade, do patrimônio geológico e da geoconservação configuram campos de atuação que mesclam os preceitos da ciência pura e da ciência aplicada. O inventário revela elementos da geodiversidade passíveis de aprofundamento de estudos científicos nas áreas da estratigrafia, geomorfologia, hidrografia, paleoambiental e petrologia.

A avaliação ratifica que o local se destaca em todos os critérios de uso (científico, turístico e educativo), alcançando valores de relevância nacional. $\mathrm{O}$ valor cientifico é o mais salientado, especialmente em função da diversidade de elementos da geodiversidade. Os índices alcançados na avaliação demonstram que o 
geossítio pode ser amplamente utilizado em atividades científicas, educativas e turísticas, tanto pelas suas aptidões como pelo baixo risco de degradação da área.

As propostas de valorização e divulgação expõe o caráter aplicado do estudo. Por meio das estratégias, que integram preceitos da geocomunicação, interpretação e educação ambiental, foi possível traduzir o conhecimento geológico acerca do geossítio para uma linguagem passível de entendimento por uma diversidade de públicos. As medidas buscaram transformar as visitas ao geossítio em atividades significativas, provocantes, diferenciadas, temáticas, organizadas, e, prazerosas, seguindo os preceitos da interpretação ambiental difundidos por Tilden (1977).

As ações apresentadas nesse estudo podem ser replicadas em diferentes regiões no país. O Brasil dispõe de um território com elevado potencial para o desenvolvimento de trabalhos voltados à geoconservação, embora careça de medidas legais que suportem essas ações. A academia brasileira tem-se mobilizado para o crescimento das temáticas nos últimos anos, mas ainda precisa de estudos com caráter propositivo e capazes de se inserir no cotidiano das pessoas.

\section{Agradecimentos}

O presente trabalho foi realizado com apoio da Coordenação de Aperfeiçoamento de Pessoal de Nível Superior - Brasil (CAPES) por meio de bolsas de Doutorado-PROEX (Código de financiamento: 88882.180701/2018-01) e de Doutorado Sanduíche no Exterior, PRINT-CAPES, Código de financiamento: 88887.364301/2019-00) concedidas ao primeiro autor.

\section{Referências}

BRILHA, J. Património Geológico e Geoconservação: A Conservação da Natureza na sua Vertente Geológica. Braga: Palimage Editores, 2005.

CAPUTO, M. V.; LIMA, E. C. Estratigrafia, idade e correlação do Grupo Serra Grande - Bacia do Parnaíba. In: Congresso Brasileiro de Geologia, 33.; 1984, Rio de Janeiro. Anais.... Rio de Janeiro: UFRJ, p. 740-753, 1984.

CARCAVILLA, L.; DURÁN, J. J.; LOPEZ-MARTÍNES, J. Geodiversidade: concepto y relación com el patrimônio geológico. Geo-Temas. v. 10, p. 1299-1303, 2008.

CARCAVILLA, L.; BERRIO, M. P.; BELMONTE, A.; DURÁN, J. J.; LÓPEZ-MARTÍNEZ, J. La divulgacíon de la Geologia al gran público: princípios y técnicas para el diseño de material escrito. Bol. R. Soc. Esp. Hist. Nat. Sec. Geol. v. 104, p. 93-110, 2010.

CAVAlCANTE, J. C. Estratigrafia Precambriana do Estado do Ceará - Uma síntese. In: Simpósio de Geologia do Nordeste.; 1993. Atas... Natal, Núcleo Nordeste da SBG, v. 13. p. 313-316, 1993.

CPRM - Serviço Geológico Brasileiro. Carta Geológica Folha Frecheirinha (AS-24-Y-C-VI) em escala de 1:100.000. Brasília, DF: CPRM, 2014.

CPRM - Serviço Geológico Brasileiro. Geossit: cadastro de sítios geológicos. 2018. Disponível em: 〈http://www.cprm.gov.br/geossit>. Acesso em 19 ago. 2019.

DUNHAM, R. J. Classification of Carbonate Rocks According to Depositional Texture. In: HAM, W.E. (Ed.). Classification of Carbonate Rocks. Tulsa: AAPG, p. 108-121, 1962.

FOLK, R. L. Petrology of Sedimentary Rocks. Austin: University of Texas Publication, 1968.

FUERTEZ-GUTIÉRREZ, I.; FERNANDES-MARTINÉZ, E. Geosites Inventory in the Leon Province (Northwestern Spain): A Tool to Introduce Geoheritage into Regional Environmental Management. Geoheritage. v. 2, p. 57-75, 2010.

GRAY, M. Geodiversity: valuing and conserving abiotic nature. Chichester: John Wiley and Sons, 2004. 434p.

GRAY, M. Geodiversity: developing the paradigm. Proceedings of the Geologists' Association, v. 119, p. 287-298, 2008.

GOÉS, A. M. O.; FEIJÓ, F. J. Bacia do Parnaíba. Boletim de Geociências da Petrobrás, v. 8, p. 57-67, 1994. 
LIMA, L. C.; MORAIS, J. O.; SOUZA, M. J. N. Compartimentação territorial e gestão regional do Ceará. Fortaleza: FUNECE, 2000.

MEIRA, S. A.; NASCIMENTO, M. A. L.; SÁ, A. A. A.; SILVA, E. V. O caminho das pedras: uma proposta de roteiro metodológico para atividades práticas em geoconservação. Estudos Geográficos, v. 15, n. 2, p. 57-77, 2017.

MOURA-FÉ, M. M. Planalto, cuesta, glint: a Geomorfologia da Ibiapaba Setentrional (região noroeste do Ceará, Brasil). Revista Brasileira de Geografia Física, v. 10, n. 6, p. 1846-1858, 2017 a.

MOURA-FÉ, M. M. Análise das unidades geomorfológicas da Ibiapaba setentrional (noroeste do estado do Ceará, Brasil). Caminhos de Geografia, v. 18, n. 63, p. 240-266, 2017 b.

PILÓ, L. B. Geomorfologia Cárstica. Revista Brasileira de Geomorfologia, v. 1, n. 1, p. 88-102, 2000.

ProGEO - The european association for the Conservation of the geological heritage. Conserving our Shared Geoheritage: A Protocol on Geoconservation Principles, Sustainable Site Use, Management, Fieldwork, Fossil and Mineral Collecting. 2011. Disponível em: 〈http://www.sigeaweb.it/geoheritage/documents/progeo-protocol-definitions-20110915.pdf >. Acesso em 19 ago. 2019.

SHARPLES, C. A. Methodology for the identification of significant landforms and geological sites for geoconservation purposes. Tasmaia: Report to Forestry Commission Tasmania, 1993.

SHARPLES, C. A. Concepts and principles of geoconservation. 2002. Disponível em: <http://dpipwe.tas.gov.au/Documents/geoconservation.pdf>. Acesso em 19 ago. 2019.

SOUZA, M. J. N.; LIMA, F. A. M.; PAIVA, J. B. Compartimentação topográfica do estado do Ceará. Ciên. Agron., v. 9, p. 77-86, 1979.

TILDEN, F. Interpreting our heritage. 3 ed. Chapel Hill: The University of North Carolina Press, 1977.

VAZ, P. T.; REZENDE, N. G. A. M.; WANDERLEY FILHO, J. R.; TRAVASSOS, W. A. S. Bacia do Parnaíba. Boletim de Geociências da Petrobrás, v. 15, n. 2, p. 253-263, 2007.

VIANA, M. S. S.; OLIVEIRA, P. V.; SOUSA, M. J. G.; BARROSO, F. R. G.; VASCONCELOS, V. A.; MELO, R. M.; LIMA, T. A.; OLIVEIRA, G. C.; CHAVES, A. P. P. Ocorrências icnofossiliferas do Grupo Serra Grande (Siluriano da Bacia Parnaíba), noroeste do estado do Ceará. Revista de Geologia, v. 23, n. 1, p. 77-89, 2010. 